\title{
Pemodelan Finite State Automata Dan Certainty Factor Untuk Sistem Pakar Diagnosa Penyakit Radang Genetalia Interna Pada Wanita
}

\author{
Vihi Atina ${ }^{1}$, Intan Oktaviani ${ }^{2}$ \\ Fakultas Ilmu Komputer Universitas Duta Bangsa Surakarta \\ Jl. Bhayangkara No. 55, Tipes, Serengan, Surakarta, Jawa Tengah \\ Email:1vihi_atina@udb.ac.id, ${ }^{2}$ intan_oktaviani@udb.ac.id
}

\begin{abstract}
Abstrak
Infeksi bakteri menyebabkan wanita rentan menderita penyakit ginekologi (reproduksi dan organ dalam wanita). Infeksi bakteri akan sulit ditangani jika wanita terlambat dalam detekni dini terhadap penyakit tersebut. Penyakit radang genitalia interna merupakan salah satu masalah penyakit ginekologi. Oleh karena itu perlu dikembangkan perangkat lunak sistem pakar sebagai alat bantu dalam mendioagnosa Penyakit Radang Genitalia Interna pada wanita. Tujuan penelitian ini adalah membuat pemodelan Finite State Automata (FSA) dan Certainty Factor (CF) untuk perancangan sistem pakar diagnosa penyakit radang genetalia interna pada wanita. Penelitian ini dikerjakan menggunakan metode pengembangan sistem Extreme Programming (XP) dengan tahapan perencanaan dan perancangan. Metode FSA digunakan dalam pemodelan sistem pakar ini sebagai metode penelusuran diagnosa atau solusi karena dapat mengenal dan menangkap pola dalam data. Metode CF digunakan dalam pemodelan sistem pakar ini untuk mengukur tingkat kepastian dalam mendiagnosis penyakit. Hasil pemodelan berupa diagram FSA dan perhitungan CF. Diagram FSA menunjukkan bahwa terdiri dari 14 state dengan 3 final state. Perhitungan CF menunjukkan persentase tingkat kepastian atau keyakinan terhadap diagnosa jenis penyakit radang genetalia interna pada wanita.
\end{abstract}

Kata kunci:certainty factor, extreme programming, finite state automata, radang genetalia interna, sistem pakar

\section{PENDAHULUAN}

Infeksi bakteri menyebabkan wanita rentan menderita penyakit ginekologi (reproduksi dan organ dalam wanita). Sebagian besar wanita tidak menyadari bahwa dirinya menderita infeksi. Ketika infeksi bakteri telah menyebar dan menimbulkan berbagai gejala yang mengganggu biasanya sebagian besar wanita baru menyadarinya.Infeksi bakteri akan sulit ditangani jika wanita terlambat dalam detekni dini terhadap penyakit tersebut.

Penyakit radang genitalia interna merupakan salah satu masalah penyakit ginekologi. Radang genitalia interna adalah peradangan akibat mikroorganisme pada vagina dalam yang mengakibatkan munculnya gejala keputihan atau fluor albus, sekitar vagina akan terasa panas, gatal, dan nyeri. Dapat terjadi demam disertai gejala nyeri perut jika infeksi menyebar ke rahim dan saluran telur. Namun beberapa gejala penyakit tersebut dianggap ringan sehingga baru akan diketahui apabila penyakit tersebut sudah memasuki stadium yang tinggi. Wanita yang sudah haid rentan terjangkit penyakit tersebut. Endometritis, Miometritis, dan Servisitis merupakan jenis penyakit radang genitalia interna yang membahayakan apabila dibiarkan (Hidayat, 2016).

Tes kepribadian rata-rata pada psikologi yaitu mengetahui kepribadian dari diri dan mengetahui pekerjaan yang sesuai dengan kepribadian yang dimiliki. Orang yang telah berpengalaman mengerjakan tes kepribadian mengetahui bahwa penyusunan tes tidaklah mungkin menyusun pertanyaan sulit yang membutuhkan perjalanan mental.

Berdasarkan data yang diperoleh dari dr.Catur Arif Raharja, Sp.OG dokter spesialis obstetri dan ginekologi di Klinik Utama Raharja Sukoharjo bahwa pada tahun 2018 perempuan yang mengalami sakit di bagian panggul, memiliki potensi penyakit endometritis dengan peningkatan hingga $60 \%$. Tahun 2018 angka kejadian miometritis mengalami peningkatan hingga $75 \%$ pada wanita yang berusia diatas 35 tahun. Angka kejadian servisitis pada wanita usia subur (usia 
20-35 tahun) pada tahun 2018 semakin meningkat hingga 40\% (Raharja, 2018).

Berdasarkan latar belakang tersebut maka perlu dikembangkan perangkat lunak sistem pakar sebagai alat bantu dalam mendioagnosa Penyakit Radang Genitalia Interna pada wanita. Sistem pakar merupakan salah satu bagian dari sistem kecerdasan buatan (Mulyanto, 2010). Metode Finite State Automata (FSA) cocok digunakan dalam pemodelan sistem pakar ini sebagai metode penelusuran diagnosa atau solusi karena dapat mengenal dan menangkap pola dalam data (Melly, 2012). Metode Certainty Factor (CF) menunjukkan ukuran kepastian terhadap suatu fakta atau aturan. CF merupakan nilai parameter klinis yang diberikan pakar untuk menunjukkan besarnya kepercayaan. Kelebihan dari metode $\mathrm{CF}$ adalah dapat mengukur sesuatu yang pasti atau tidak pasti dalam pengambilan keputusan pada sistem pakar diagnosa penyakit (Setyaputri,2018). Dalam penelitian ini penulis membuat pemodelan Finite State Automata (FSA) dan Certainty Factor (CF) yang dapat dijadikan acuan dalam membangun sistem pakar diagnosa penyakit radang genetalia interna pada wanita.

\section{METODE PENELITIAN}

Salah satu metode Agile adalah Extreme Programing (XP). Metode XP sesuai untuk pengembangan sistem informasi atau perangkat lunak berskala kecil sampai menengah. Tahapan-tahapan dalam metode XP sebagai berikut (Sarosa, 2017):

1. Perencanaan

Dalam perencanaan disusun ruang lingkup aplikasi, prioritas fungsi dan fitur yang harus dikembangkan dan apa yang harus dikerjakan untuk setiap tahap secara terpetinci.

2. Perancangan

Prinsip perancangan yang digunakan dalam metode XP adalah kesederhanaan, umpan balik, dan memungkinkan adanya perubahan secara bertahap. Kesederhanaan berarti pengembang menggunakan langkah yang paling mudah dalam mewujudkan suatu fungsionalitas sistem.

3. Penulisan Kode Sumber

Konsep pemrograman berpasangan diterapkan dan digunakan secara intensif.

4. Produksi
Keseluruhan modul sistem yang dikembangkan secara komprehensif dalam tahapan ini. Pengujian tersebut bermaksud memastikan bahwa aplikasi yang dikembangkan berjalan dengan optimal.

Metode XP yang digunakan dalan penelitian ini adalah 2 tahapan yaitu perencanaan dan perancangan.

\section{TINJAUAN PUSTAKA}

a. Penelitian Terdahulu

Kurnianto, dkk (2016) dalam penelitian yang berjudul "Sistem Pakar Diagnosa Penyakit Kelamin pada Pria Menggunakan Metode Forward Chaining dan Certainty Factor Berbasis Web". Penelitian ini bertujuan untuk menyusun sebuah sistem pakar yang bisa digunakan untuk mendiagnosa jenis penyakit kelamin pada pria, dimana pengguna bisa mendiagnosa sendiri berdasarkan gejala yang dialami. Sistem pakar ini dibuat karena terbatasnya pengetahuan di masyarakat terhadap penyakit kelamin dan gejalagejalanya. Sistem pakar untuk diagnosa penyakit kelamin pria ini dibuat dengan menerapkan kombinasi metode forward chaining dan metode certainty factor. Sistem tersebut memberikan hasil berupa kemungkinan penyakit kelamin yang dialami oleh pengguna, diagnosa pada sistem ini dilakukan dengan cara pengguna mengisi keluhan atau gejala yang dialami ketika menggunakan sistem ini.

Krisnandayu dan Pakereng (2016) dalam penelitian yang berjudul "Diagnosa

Penyakit Hemeroid Menggunakan Finite State Automata". Penelitian ini dilakukan karena masyarakat menganggap hemoroid merupakan penyakit yang biasa saja. Hemoroid merupakan pelebaran pembuluh darah vena di sekitar anus. Penyakit hemoroid ini membuat ketidaknyamanan bagi penderitanya sehingga beberapa orang merasa malu untuk bertemu dokter ataupun melakukan pemeriksaan. Selain itu, dibutuhkan waktu yang cukup jika harus berkonsultasi dengan dokter ahli. Untuk itu, masyarakat memerlukan sistem pakar yang dapat memudahkan mendiagnosa penyakit hemoroid sejak dini, sehingga dapat dilakukan penanganan lebih awal. Metode yang digunakan dalam penelitian ini adalah Finite State Automata. Perancangan N-DFA dapat digunakan sebagai acuan perancangan sebuah program untuk menghasilkan diagnosa penyakit hemoroid.Hasil pengujian tersebut 
dapat disimpulkan bahwa akurasi sistem diagnosa penyakit hemoroid menggunakan Finite State Automata dengan 25 data yang diuji adalah $100 \%$ yang menunjukkan bahwa sistem ini dapat berfungsi dengan baik sesuai hasil diagnosa pakar. Metode Automata memiliki kelebihan yaitu dapat digunakan untuk memodelkan pemecahan masalah/ solusi dari aplikasi yang berbasis kecerdasan buatan dan dapat menyederhanakan struktur yang digunakan, apabila terdapat beberapa keadaan yang diulang.

Aji, dkk (2018) dalam penelitian yang berjudul "Sistem Pakar Diagnosa Penyakit Ibu Hamil menggunakan Metode Certainty Factor (CF)". Penelitian ini dilakukan karena kurangnya pengetahuan mengenai gejala yang dirasakan saat masa kehamilan membuat ibu hamil tidak menghiraukan gejala-gejala tertentu yang dapat mengindikasi penyakit berbahaya dan menjadi penyebab tidak langsung kematian ibu hamil. Selain itu, resiko kematian ibu juga semakin tinggi akibat adanya faktor keterlambatan mengambil keputusan untuk dirujuk. Sistem pakar diagnosa penyakit ibu hamil menggunakan metode Certanty Factor (CF) yang dapat membantu mengenali penyakit selama kehamilan berlangsung berdasarkan gejalagejala yang dirasakan ibu hamil serta tempat rujukan yang harus dituju oleh pasien. Metode CF memiliki kinerja sistem yang mampu berjalan sesuai kebutuhan fungsional dan hasil presentase akurasi tinggi. Selain itu metode CF dapat mengambarkan tingkat keyakinan seorang pakar terhadap masalah yang sedang dihadapi. Berdasarkan hasil pengujian, diperoleh hasil $100 \%$ fungsionalitas sistem pakar diagnosa penyakit ibu hamil berjalan sesuai dengan daftar kebutuhan sistem dan sistem mempunyai tingkat akurasi sebesar $100 \%$.

\section{b. Finite State Automata (FSA)}

Metode Finite State Automata (FSA) merupakan model yang dapat menerima input dan mengeluarkan output yang memiliki state yang berhingga banyaknya dan dapat berpindah dari satu state ke state lainnya berdasarkan input dan fungsi transisi. Secara formal Finite State Automata dinyatakan oleh 5 tupel, dimana (Utdirartatmo, 2005):

$\mathrm{Q}=$ himpunan state / kedudukan

$\Sigma=$ himpunan simbol input / masukan / abjad $\mathrm{d} \quad=$ fungsi transisi

$\mathrm{S}=$ state awal / kedudukan awal (initial state)

$\mathrm{F} \quad=$ himpunan state akhir

Kontrol terhadap FSA dapat bersifat deterministik (automata tidak dapat berada di lebih dari satu status pada saat bersamaan) atau nondeterministik (automata dapat berada di beberapa status pada saat yang bersamaan) sehingga FSA terdiri dari 2 jenis yaitu : Deterministic Finite Automata (DFA) dan Non Deterministik Finite Automata (NFA). NFA memiliki kelebihan yaitu automata di dalam menerima input dapat mempunyai lebih dari satu busur keluar atau tidak punya busur keluar. (Hopcroft, 2007).

\section{c. Certainty Factor (CF)}

Certainty Factor (CF) merupakan sebuah metode yuntuk mengakomodasi ketidakpastian pemikiran (inexact reasoning) seorang pakar. Seorang pakar (contoh: dokter) sering menganalisi informasi dengan ungkapan "mungkin",

"kemungkinan besar", "hampir pasti". Sehingga dengan adanya metode Certainty Factor ini dapat mengambarkan tingkat keyakinan seorang pakar terhadap masalah yang sedang dihadapi. Saat ini ada dua model yang sering digunakan untuk mendapatkan tingkat keyakinan $(\mathrm{CF})$, yaitu

(Sutojo, 2011):

1. Metode „Net Beliefe yang diusulkan oleh E.H. Shortliffe dan B. G. Buchanan. Seperti yang ditunjukkan pada persamaan (1).

$$
\mathrm{CF}(\text { Rule })=\mathrm{MB}(\mathrm{H}, \mathrm{E})-\mathrm{MD}(\mathrm{H}, \mathrm{E}) \ldots(. . .(1)
$$

Di mana:

CF(Rule) : Faktor kepastian

$\operatorname{MB}(\mathbf{H}, \mathbf{E})$ : Measure of Belief (ukuran kepercayaan) terhadap hipotesis $\mathrm{H}$, jika diberikan evidence $\mathrm{E}$ (antara 0 dan 1) $\mathbf{M D}(\mathbf{H}, \mathbf{E})$ : Measure of Disbelief (ukuran ketidak percayaan) terhadap evidence $\mathrm{H}$, jika diberikan evidence $\mathrm{E}$ (antara 0 dan 1)

2. Menggunakan hasil wawancara dengan pakar. Dengan mendapatkan informasi dari hasil wawancara dengan pakar. Nilai $\mathrm{CF}($ Rule) didapat dari intrepretasi "term" dari pakar, yang diubah menjadi nilai $\mathrm{CF}$ tertentu. 


\section{HASIL DAN PEMBAHASAN}

a. Perancanaan

Tahap perencanaan dilakukan untuk mengetahui mengenai konsep sistem pakar. Proses pencarian data pada tahap ini dilakukan kepada seorang yang ahli di bidang ginekologi. Studi kasus yang digunakan dalam penelitian ini adalah Klinik Utama Raharja yang beralamatkan di Tawangrejo, Ngreco, Weru, Sukoharjo. Berdasarkan hasil dari pengumpulan data berupa wawancara dengan dokter spesialis kebidanan dan penyakit kandungan (pakar ginekologi) dr.Catur Arif Raharja, Sp.OG diperoleh daftar penyakit radang gnetalia interna, untuk lebih jelas dapat dilihat pada tabel 1 .

Tabel 1. Data Penyakit

\begin{tabular}{|c|c|c|}
\hline $\begin{array}{c}\text { Kode } \\
\text { Penya } \\
\text { kit } \\
\end{array}$ & $\begin{array}{c}\text { Nama } \\
\text { Penya } \\
\text { kit }\end{array}$ & Keterangan \\
\hline P001 & $\begin{array}{l}\text { Endo } \\
\text { metriti } \\
\quad \mathrm{s} \\
\text { (perad } \\
\text { angan } \\
\text { endom } \\
\text { etrium } \\
\text { ) }\end{array}$ & $\begin{array}{l}\text { Kondisi dimana adanya } \\
\text { peradangan pada uterus, } \\
\text { dan seringnya disertai } \\
\text { infeksi disana. Uterus } \\
\text { atau rahim adalah organ } \\
\text { reproduksi utama pada } \\
\text { perempuan dimana pada } \\
\text { organ tersebut janin bayi } \\
\text { berkembang Selama } \\
\text { kehamilan. }\end{array}$ \\
\hline P002 & $\begin{array}{l}\text { Miom } \\
\text { etritis }\end{array}$ & $\begin{array}{l}\text { Merupakan } \\
\text { infeksi uterus setelah } \\
\text { persalinan } \\
\text { merupakan salah satu } \\
\text { penyebab terbesar } \\
\text { kematian ibu. Biasa nya } \\
\text { tidak berdiri sendiri } \\
\text { tetapi lanjutan dari } \\
\text { endometriosis. }\end{array}$ \\
\hline P003 & $\begin{array}{c}\text { Cervic } \\
\text { itis }\end{array}$ & $\begin{array}{lr}\text { Kondisi pada proses } \\
\text { peradangan } & \text { yang } \\
\text { melibatkan } & \text { epitel } \\
\text { serviks dan stroma yang } \\
\text { mendasarinya sering di } \\
\text { jumpai bersama dengan } \\
\text { vaginitis atau sebagai } \\
\text { suatu manifestasi } \\
\text { penyakit penyakit yang } \\
\text { ditularkan melalui } \\
\text { hubungan seks. } \\
\text { Servisitis } \\
\text { tricomonas vaginalis , } \\
\text { candid albicans dan } \\
\text { gardnerella vaginalis } \\
\text { dapat }\end{array}$ \\
\hline
\end{tabular}

\begin{tabular}{|l|l|l|}
\hline & $\begin{array}{l}\text { manifestasi minor } \\
\text { vaginitis. }\end{array}$ \\
\hline
\end{tabular}

Data gejala yang diperoleh dapat dilihat pada tabel 2 .

Tabel 2. Data Gejala

\begin{tabular}{|c|l|}
\hline $\begin{array}{c}\text { Kode } \\
\text { Gejala }\end{array}$ & \multicolumn{1}{|c|}{ Nama Gejala } \\
\hline G001 & $\begin{array}{l}\text { Peningkatan demam secara } \\
\text { persisten hingga 40 derajat } \\
\text { celcius }\end{array}$ \\
\hline G002 & Perdarahan pervaginam. \\
\hline G003 & $\begin{array}{l}\text { Abdomen distensi atau } \\
\text { pembengkakan perut }\end{array}$ \\
\hline G004 & Nyeri panggul \\
\hline G005 & $\begin{array}{l}\text { Sakit saat buang air besar } \\
\text { (sembelit) }\end{array}$ \\
\hline G006 & $\begin{array}{l}\text { Keluar lochea berbau / purulent / } \\
\text { keputihan yg berbau }\end{array}$ \\
\hline G007 & $\begin{array}{l}\text { Terjadi ketidaknyamanan, } \\
\text { kegelisahan, atau perasaan sakit } \\
\text { (malaise) }\end{array}$ \\
\hline G008 & Demam \\
\hline G009 & Sakit pinggang \\
\hline G010 & Nyeri abdomen atau nyeri perut \\
\hline G011 & $\begin{array}{l}\text { Perdarahan saat melakukan } \\
\text { hubungan seks }\end{array}$ \\
\hline G012 & $\begin{array}{l}\text { Perdarahan sesudah mati haid } \\
\text { (menopause) }\end{array}$ \\
\hline $\begin{array}{l}\text { Keluar cairan abnormal } \\
\text { (kekuning-kuningan, berbau dan } \\
\text { bercampur darah). }\end{array}$ \\
\hline G013
\end{tabular}

Data solusi yang diperoleh dapat dilihat pada tabel 3 .

Tabel 3. Data Solusi

\begin{tabular}{|l|l|}
\hline $\begin{array}{c}\text { Kode } \\
\text { Solusi }\end{array}$ & \multicolumn{1}{|c|}{ Nama Solusi } \\
\hline S001 & $\begin{array}{l}\text { Untuk meredakan nyeri bisa } \\
\text { dengan mandi air hangat atau } \\
\text { kompres hangat. }\end{array}$ \\
\hline S002 & Olahraga teratur. \\
\hline S003 & Pemberian Antiseptik. \\
\hline S004 & Terapi Antibiotika \\
\hline S005 & $\begin{array}{l}\text { Pemberian cairan intraven dan } \\
\text { elektrolit (terapi pengganti untuk } \\
\text { dehidrasi terapi } \\
\text { pemeliharaan). }\end{array}$ \\
\hline S006 & Menjaga kebersihan vagina. \\
\hline S007 & $\begin{array}{l}\text { Menyembuhkan penyakit } \\
\text { metabolisme. }\end{array}$ \\
\hline S008 & $\begin{array}{l}\text { Memenuhi } \\
\text { magnesium. }\end{array}$ \\
\hline
\end{tabular}




\begin{tabular}{|c|c|}
\hline $\begin{array}{l}\text { Kode } \\
\text { Solusi }\end{array}$ & Nama Solusi \\
\hline S009 & Memperbaiki kebutuhan nutrisi. \\
\hline S010 & $\begin{array}{l}\text { Antibiotika spektrum luas: } \\
\text { - Ampisilin } 2 \mathrm{~g} \text { iv / } 6 \text { jam } \\
\text { - Gentamisin } 5 \mathrm{mg} \mathrm{kgbb} \\
\text { - Metronidasol } 500 \mathrm{mg} \text { iv / } 8 \\
\text { jam. }\end{array}$ \\
\hline S011 & $\begin{array}{l}\text { Memberikan dukungan } \\
\text { emosional kepada penderita. }\end{array}$ \\
\hline S012 & Berpantang aktivitas seksual. \\
\hline S013 & $\begin{array}{l}\text { Hindari hal apapun yag dapat } \\
\text { mengiritasi vagina. }\end{array}$ \\
\hline S014 & $\begin{array}{l}\text { Kenakan celana dalam nyaman } \\
\text { berbahan katun. }\end{array}$ \\
\hline
\end{tabular}

Data relasi antara gejala dan penyakit dapat dilihat pada tabel 4 .

Tabel 4. Relasi Data Penyakit dan Gejala
\begin{tabular}{|c|c|c|c|}
\hline \multirow{2}{*}{ Kode } & \multicolumn{3}{|c|}{ Kode Penyakit } \\
\hline Gejala & P001 & P002 & P003 \\
\hline G001 & $\sqrt{ }$ & & \\
\hline G002 & $\sqrt{ }$ & & \\
\hline G003 & $\sqrt{ }$ & & \\
\hline G004 & $\sqrt{ }$ & & \\
\hline G005 & $\sqrt{ }$ & & \\
\hline G006 & $\sqrt{ }$ & $\sqrt{ }$ & $\sqrt{ }$ \\
\hline G007 & $\sqrt{ }$ & & \\
\hline G008 & & $\sqrt{ }$ & \\
\hline G009 & & $\sqrt{ }$ & \\
\hline G010 & & $\sqrt{ }$ \\
\hline G011 & & & $\sqrt{ }$ \\
\hline G012 & & & $\sqrt{ }$ \\
\hline G013 & & & $\sqrt{ }$ \\
\hline
\end{tabular}

Data relasi antara penyakit dan solusi dapat dilihat pada tabel 5 .

Tabel 5. Relasi Data Penyakit dan Solusi

\begin{tabular}{|c|c|c|c|}
\hline \multirow{2}{*}{ Kode } & \multicolumn{3}{|c|}{ Kode Penyakit } \\
\hline & P001 & P002 & P003 \\
\hline S001 & $\sqrt{ }$ & & \\
\hline S002 & $\sqrt{ }$ & & \\
\hline S003 & $\sqrt{ }$ & $\sqrt{ }$ & $\sqrt{ }$ \\
\hline S004 & $\sqrt{ }$ & & $\sqrt{ }$ \\
\hline S005 & $\sqrt{ }$ & & \\
\hline S006 & & $\sqrt{ }$ & $\sqrt{ }$ \\
\hline S007 & & $\sqrt{ }$ & \\
\hline S008 & & $\sqrt{ }$ & \\
\hline S009 & & $\sqrt{ }$ & \\
\hline S010 & & $\sqrt{ }$ & \\
\hline S011 & & $\sqrt{ }$ & \\
\hline S012 & & & $\sqrt{ }$ \\
\hline S013 & & & $\sqrt{ }$ \\
\hline
\end{tabular}

\section{\begin{tabular}{|l|l|l|l|}
\hline S014 & & & $\sqrt{ }$ \\
\hline
\end{tabular}}

\section{b. Perancangan}

Tahap perancangan dalam penelitian ini terdiri dari 2 pemodelan basis pengetahuan yaitu pemodelan Finite State Automata dan certainty faktor untuk sistem pakar diagnosa penyakit radang genetalia interna pada wanita.

\section{a) Pemodelan Finite Sate Automata}

Berdasarkan data yang diperoleh dari tahap perencanaan maka model Finite State Automata untuk sistem pakar tersebut dapat dinyatakan sebagai berikut :

$$
\begin{aligned}
\mathrm{Q}= & \{\mathrm{q} 0, \mathrm{q} 1, \mathrm{q} 2, \mathrm{q} 3, \mathrm{q} 4, \mathrm{q} 5, \mathrm{q} 6, \mathrm{q} 7, \mathrm{q} 8, \\
& \mathrm{q} 9, \mathrm{q} 10, \mathrm{q} 11, \mathrm{q} 12, \mathrm{q} 13\} \\
\Sigma \quad= & \{\mathrm{G} 001, \mathrm{G} 002, \mathrm{G} 003, \mathrm{G} 004, \mathrm{G} 005, \\
& \mathrm{G} 006, \mathrm{G} 007, \mathrm{G} 008, \mathrm{G} 009, \mathrm{G} 010, \\
& \mathrm{G} 011, \mathrm{G} 012, \mathrm{G} 013\} \\
\mathrm{S} \quad= & \{\mathrm{q} 0\} \\
\mathrm{F} \quad= & \{\mathrm{q} 8, \mathrm{q} 11, \mathrm{q} 13\} \\
\mathrm{d} \quad= & \text { fungsi transisi dapat dilihat pada } \\
& \text { tabel } 6
\end{aligned}
$$

Tabel 8. Transisi Finite State Automata

\begin{tabular}{|c|c|c|c|c|c|c|c|c|c|c|c|c|c|}
\hline $\boldsymbol{\delta}$ & $\mathrm{G}$ & $\mathrm{G}$ & $\mathrm{G}$ & $\mathrm{G}$ & $\mathrm{G}$ & $\mathrm{G}$ & $\mathrm{G}$ & $\mathrm{G}$ & $\mathrm{G}$ & $\mathrm{G}$ & $\mathrm{G}$ & $\mathrm{G}$ & $\mathrm{G}$ \\
& 0 & 0 & 0 & 0 & 0 & 0 & 0 & 0 & 0 & 0 & 0 & 0 & 0 \\
& 0 & 0 & 0 & 0 & 0 & 0 & 0 & 0 & 0 & 1 & 1 & 1 & 0 \\
& 1 & 2 & 3 & 4 & 5 & 6 & 7 & 8 & 9 & 0 & 1 & 2 & 1 \\
\hline $\mathrm{q}$ & $\varnothing$ & $\varnothing$ & $\varnothing$ & $\varnothing$ & $\varnothing$ & $\mathrm{q}$ & $\varnothing$ & $\varnothing$ & $\varnothing$ & $\varnothing$ & $\varnothing$ & $\varnothing$ & $\varnothing$ \\
0 & & & & & & 1 & & & & & & & \\
\hline $\mathrm{q}$ & $\mathrm{q}$ & $\varnothing$ & $\varnothing$ & $\varnothing$ & $\varnothing$ & $\varnothing$ & $\varnothing$ & $\varnothing$ & $\varnothing$ & $\varnothing$ & $\varnothing$ & $\varnothing$ & $\varnothing$ \\
1 & 2 & & & & & & & & & & & & \\
\hline $\mathrm{q}$ & $\varnothing$ & $\mathrm{q}$ & $\varnothing$ & $\varnothing$ & $\varnothing$ & $\varnothing$ & $\varnothing$ & $\mathrm{q}$ & $\varnothing$ & $\varnothing$ & $\varnothing$ & $\varnothing$ & $\varnothing$ \\
2 & & 3 & & & & & & 4 & & & & & \\
\hline $\mathrm{q}$ & $\varnothing$ & $\varnothing$ & $\mathrm{q}$ & $\varnothing$ & $\varnothing$ & $\varnothing$ & $\varnothing$ & $\varnothing$ & $\varnothing$ & $\varnothing$ & $\varnothing$ & $\varnothing$ & $\varnothing$ \\
3 & & & 5 & & & & & & & & & & \\
\hline $\mathrm{q}$ & $\varnothing$ & $\varnothing$ & $\varnothing$ & $\varnothing$ & $\varnothing$ & $\varnothing$ & $\varnothing$ & $\varnothing$ & $\mathrm{q}$ & $\varnothing$ & $\mathrm{q}$ & $\varnothing$ & $\varnothing$ \\
4 & & & & & & & & & 9 & & 1 & & \\
\hline $\mathrm{q}$ & $\varnothing$ & $\varnothing$ & $\varnothing$ & $\mathrm{q}$ & $\varnothing$ & $\varnothing$ & $\varnothing$ & $\varnothing$ & $\varnothing$ & $\varnothing$ & $\varnothing$ & $\varnothing$ & $\varnothing$ \\
5 & & & & 6 & & & & & & & & & \\
\hline $\mathrm{q}$ & $\varnothing$ & $\varnothing$ & $\varnothing$ & $\varnothing$ & $\mathrm{q}$ & $\varnothing$ & $\varnothing$ & $\varnothing$ & $\varnothing$ & $\varnothing$ & $\varnothing$ & $\varnothing$ & $\varnothing$ \\
6 & & & & & 7 & & & & & & & & \\
\hline $\mathrm{q}$ & $\varnothing$ & $\varnothing$ & $\varnothing$ & $\varnothing$ & $\varnothing$ & $\varnothing$ & $\mathrm{q}$ & $\varnothing$ & $\varnothing$ & $\varnothing$ & $\varnothing$ & $\varnothing$ & $\varnothing$ \\
7 & & & & & & & 8 & & & & & & \\
\hline $\mathrm{q}$ & $\varnothing$ & $\varnothing$ & $\varnothing$ & $\varnothing$ & $\varnothing$ & $\varnothing$ & $\varnothing$ & $\varnothing$ & $\varnothing$ & $\varnothing$ & $\varnothing$ & $\varnothing$ & $\varnothing$ \\
8 & & & & & & & & & & & & & \\
\hline $\mathrm{q}$ & $\varnothing$ & $\varnothing$ & $\varnothing$ & $\varnothing$ & $\varnothing$ & $\varnothing$ & $\varnothing$ & $\varnothing$ & $\varnothing$ & $\mathrm{q}$ & $\varnothing$ & $\varnothing$ & $\varnothing$ \\
9 & & & & & & & & & & 1 & & & \\
\hline $\mathrm{q}$ & $\varnothing$ & $\varnothing$ & $\varnothing$ & $\varnothing$ & $\varnothing$ & $\varnothing$ & $\varnothing$ & $\varnothing$ & $\varnothing$ & $\varnothing$ & $\varnothing$ & $\mathrm{q}$ & $\varnothing$ \\
1 & & & & & & & & & & & & 1 & \\
0 & & & & & & & & & & & & 2 & \\
\hline $\mathrm{q}$ & $\varnothing$ & $\varnothing$ & $\varnothing$ & $\varnothing$ & $\varnothing$ & $\varnothing$ & $\varnothing$ & $\varnothing$ & $\varnothing$ & $\varnothing$ & $\varnothing$ & $\varnothing$ & $\varnothing$ \\
\hline
\end{tabular}




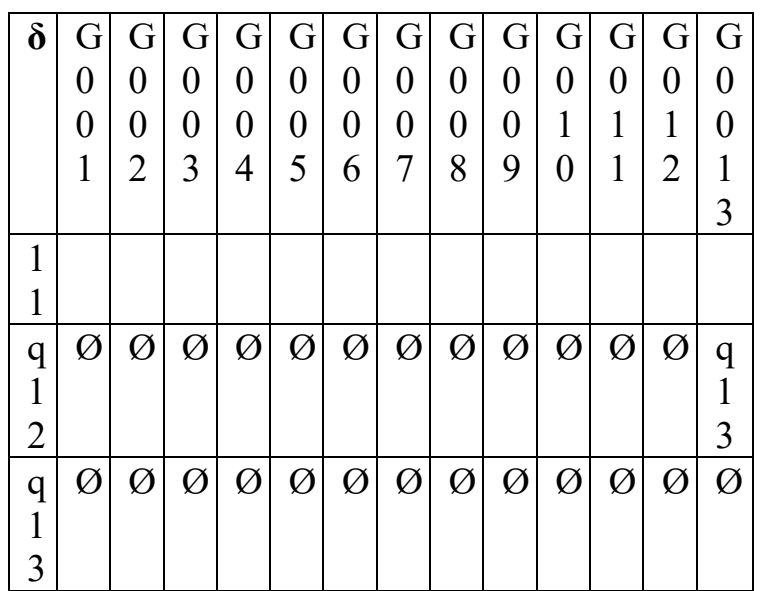

Pemodelan Finite State Automata dapat untuk sistem pakar dilihat pada diagram FSA gambar 1.

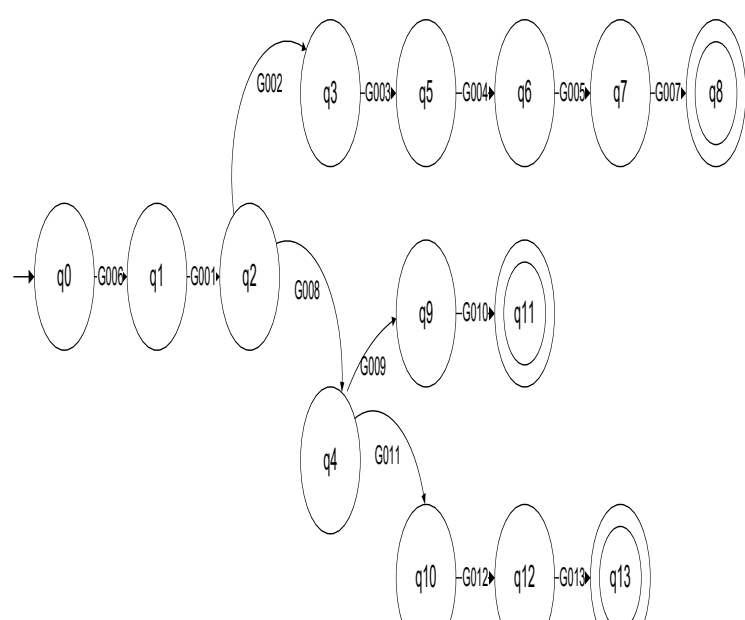

Gambar 1. Diagram Finite State Automata Keterangan gambar 1:

$\mathrm{q} 0=$ status awal

$\mathrm{q} 1=$ mengenali gejala G006

$\mathrm{q} 2$ = mengenali gejala G001

$\mathrm{q} 3=$ mengenali gejala $\mathrm{G} 002$

$\mathrm{q} 4=$ mengenali gejala $\mathrm{G} 008$

q5 = mengenali gejala $\mathrm{G} 003$

q6 = mengenali gejala G004

q7 = mengenali gejala G005

q8 = mengenali gejala G007, penyakit P001, solusi S001, S002, S003, S004 dan S005

q9 = mengenali gejala G009

$\mathrm{q} 10=$ mengenali gejala $\mathrm{G} 011$

q11 = mengenali gejala G010, penyakit $\mathrm{P} 002$, solusi S003, S006, S007, S008, S009,

S010,dan S011

q12 = mengenali gejala G012

q13 = mengenali gejala G013, penyakit P003, solusi S003, S004, S006, S012, S013, S014

\section{b) Pemodelan Certainty Factor}

Data nilai CF yang diperoleh dari pakar dapat dilihat pada tabel 9 .

Tabel 9. Data Nilai CF dari Pakar

\begin{tabular}{|c|c|c|c|}
\hline $\begin{array}{l}\mathrm{N} \\
\mathrm{O}\end{array}$ & $\begin{array}{c}\text { Nama } \\
\text { Penya } \\
\text { kit }\end{array}$ & Gejala & $\mathbf{C F}$ \\
\hline \multirow{7}{*}{1.} & \multirow{7}{*}{$\begin{array}{l}\text { Endo } \\
\text { metriti } \\
\text { s } \\
\text { (perad } \\
\text { angan } \\
\text { endom } \\
\text { etrium } \\
\quad \text { ) }\end{array}$} & $\begin{array}{l}\text { Peningkatan demam } \\
\text { secara persisten hingga } \\
40 \text { derajat celcius }\end{array}$ & 0,4 \\
\hline & & $\begin{array}{l}\text { Perdarahan } \\
\text { pervaginam. }\end{array}$ & 0,6 \\
\hline & & $\begin{array}{l}\text { Abdomen distensi atau } \\
\text { pembengkakan perut }\end{array}$ & 0,8 \\
\hline & & Nyeri panggul & 0,4 \\
\hline & & $\begin{array}{l}\text { Sakit saat buang air } \\
\text { besar (sembelit) }\end{array}$ & 0,8 \\
\hline & & $\begin{array}{l}\text { Keluar lochea berbau / } \\
\text { purulent / keputihan yg } \\
\text { berbau }\end{array}$ & 0,6 \\
\hline & & $\begin{array}{l}\text { Terjadi ketidaknyama } \\
\text { nan, kegelisahan, atau } \\
\text { perasaan sakit } \\
\text { (malaise) }\end{array}$ & 0,4 \\
\hline \multirow{4}{*}{2.} & \multirow{4}{*}{$\begin{array}{l}\text { Miom } \\
\text { etritis }\end{array}$} & Demam & 0,6 \\
\hline & & $\begin{array}{l}\text { Keluar lochea berbau / } \\
\text { purulent / keputihan yg } \\
\text { berbau }\end{array}$ & 0,6 \\
\hline & & Sakit pinggang & 0,4 \\
\hline & & $\begin{array}{l}\text { Nyeri abdomen atau } \\
\text { nyeri perut }\end{array}$ & 0,4 \\
\hline \multirow{4}{*}{3.} & \multirow{4}{*}{$\begin{array}{l}\text { Servic } \\
\text { itis }\end{array}$} & $\begin{array}{l}\text { Perdarahan saat } \\
\text { melakukan hubungan } \\
\text { seks }\end{array}$ & 0,8 \\
\hline & & $\begin{array}{l}\text { Keluar lochea berbau / } \\
\text { purulent / keputihan } \\
\text { yang berbau }\end{array}$ & 0,6 \\
\hline & & $\begin{array}{l}\text { Perdarahan sesudah } \\
\text { mati haid (menopause) }\end{array}$ & 0,4 \\
\hline & & $\begin{array}{l}\text { Keluar cairan } \\
\text { abnormal (kekuning- } \\
\text { kuningan, berbau dan } \\
\text { bercampur darah). }\end{array}$ & 0,6 \\
\hline
\end{tabular}

Bobot user menggunakan 3 pilihan kategori jawaban sebagai berikut:

a) Pilihan jawaban "Ya" nilai bobotnya 1

b) Pilihan jawaban "Mungkin" nilai bobotnya 0,5

c) Pilihan jawaban "Tidak" nilai bobotnya 0

Misalnya user memilih 7 gejala sebagai berikut:

a) G004 Nyeri panggul (yakin) 
b) G006 Keluar lochea berbau / purulent / keputihan yg berbau (mungkin)

c) G007 Terjadi ketidak nyamanan, kegelisahan, atau perasaan sakit (malaise) (mungkin)

d) G008 Demam (mungkin)

e) G010 Nyeri abdomen atau nyeri perut (yakin)

f) G011 Perdarahan saat melakukan hubungan seks (yakin)

g) G013 Keluar cairan abnormal (kekuningkuningan, berbau dan bercampur darah) (mungkin)

Maka nilai CF Pakar dikalikan dengan Bobot Nilai dari jawaban user dapat dilihat pada tabel 10.

\begin{tabular}{|c|c|c|}
\hline $\begin{array}{l}\text { Kode } \\
\text { Gejala }\end{array}$ & $\begin{array}{l}\text { CF Pakar x } \\
\text { Bobot User }\end{array}$ & $\begin{array}{c}\text { Nama } \\
\text { Penyakit }\end{array}$ \\
\hline G004 & $0,4 \times 1=\mathbf{0 , 4}$ & \multirow{3}{*}{$\begin{array}{l}\text { Endometrit } \\
\text { is }\end{array}$} \\
\hline G006 & $0,6 \times 0,5=\mathbf{0 , 3}$ & \\
\hline G007 & $0,4 \times 0,5=\mathbf{0 , 2}$ & \\
\hline G006 & $0,6 \times 0,5=\mathbf{0 , 3}$ & \multirow{3}{*}{ Miometritis } \\
\hline G008 & $0,6 \times 0,5=\mathbf{0}, 3$ & \\
\hline G010 & $0,4 \times 1=\mathbf{0 , 4}$ & \\
\hline G006 & $0,6 \times 0,5=\mathbf{0 , 3}$ & \multirow{3}{*}{ Servicitis } \\
\hline G011 & $0,8 \times 1=\mathbf{0}, 8$ & \\
\hline G013 & $0,6 \times 0,5=\mathbf{0 , 3}$ & \\
\hline
\end{tabular}

Pemodelan Certainty Factor dihitung dengan mengkombinasikan nilai $\mathrm{CF}$ dari masingmasing rule sebagai berikut:

a) Endometritis

$$
\begin{aligned}
& \mathrm{CF} 1=\mathrm{CFk} 1+[\mathrm{CFk} 2 *(1-\mathrm{CFk} 1)] \\
& =0,4+[0,3 *(1-0,4)] \\
& =0,4+[0,3 \times 0,6] \\
& =0,4+0,18 \\
& =0,58=58 \%
\end{aligned}
$$

$\mathrm{CF} 2=\mathrm{CF} 1+[\mathrm{CFk} 3 *(1-\mathrm{CF} 1)]$

$=0,58+[0,2 *(1-0,58)]$

$=0,58+[0,2 \times 0,42]$

$=0,58+0,084$

$=0,664=\mathbf{6 6}, 4 \%$

b) Miometritis

$\mathrm{CF} 1=\mathrm{CFk} 1+[\mathrm{CFk} 2 *(1-\mathrm{CFk} 1)]$

$=0,3+[0,3 *(1-0,3)]$

$=0,3+[0,3 \times 0,7]$

$=0,4+0,21$

$=0,61=61 \%$

$$
\begin{aligned}
& \mathrm{CF} 2=\mathrm{CF} 1+[\mathrm{CFk} 3 *(1-\mathrm{CF} 1)] \\
& =0,61+[0,4 *(1-0,61)] \\
& =0,61+[0,4 \times 0,39] \\
& =0,61+0,156 \\
& =0,766=\mathbf{7 6 , 6 \%}
\end{aligned}
$$

\section{c) Servicitis}

$\mathrm{CF} 1=\mathrm{CFk} 1+[\mathrm{CFk} 2 *(1-\mathrm{CFk} 1)]$

$=0,3+[0,8 *(1-0,3)]$

$=0,3+[0,8 \times 0,7]$

$=0,3+0,56$

$=0,86=86 \%$

$$
\begin{aligned}
& \mathrm{CF} 2=\mathrm{CF} 1+[\mathrm{CFk} 3 *(1-\mathrm{CF} 1)] \\
& =0,86+[0,3 *(1-0,86)] \\
& =0,86+[0,3 \times 0,14] \\
& =0,86+0,042 \\
& =0,902=\mathbf{9 0 , 2} \%
\end{aligned}
$$

Berdasarkan hasil perhitungan nilai $\mathrm{CF}$ maka kesimpulan hasil diagnosa diambil jenis penyakit yang memiliki nilai persentase terbesar, maka dapat disimpulkan bahwa berdasarkan data dari user yang sudah melakukan diagnosa menunjukan terdiagnosa penyakit Servicitis dengan tingkat persentase keyakinan $90,2 \%$.

\section{KESIMPULAN DAN SARAN}

\section{a. Kesimpulan}

Kesimpulan berdasarkan hasil penelitian adalah sebagai berikut :

1) Penelitian dibuat menggunakan tahapan metode pengembangan sistem Extreme Programing (XP) yaitu tahap perencanaan dan perancangan.

2) Tahap perencanaan diperoleh data penyakit, gejala, solusi, relasi antara penyakit dan gejala serta relasi antara penyakit dan solusi.

3) Pemodelan Finite State Automata yang dihasilkan dari tahap perancangan dalam bentuk diagram yang terdiri dari 14 state dan 3 final state.

4) Pemodelan Certainty Factor yang dihasilkan dari tahap perancangan berupa persentase tingkat kepastian atau keyakinan terhadap diagnosa jenis penyakit radang genetalia interna pada wanita.

\section{b. Saran}

Berdasarkan hasil kesimpulan maka penulis memberikan saran bahwa pemodelan 
Finite State Automata dan Certainty Factor tersebut dapat digunakan sebagai acuan dalam membangun sistem pakar diagnosa penyakit radang getalia interna pada wanita.

\section{c. Ucapan Terimakasih}

Kami sangat berterima kasih kepada Kemenristek-Dikti atau Kementerian Riset dan Pendidikan Tinggi Indonesia (DPRM-DIKTI) yang membiayai penelitian ini dan dr.Catur Arif Raharja, Sp.OG yang bersedia berpartisipasi dalam penelitian ini.

\section{REFERENSI}

Aji, A. H., Furqon, M. T. dan Widodo, A.W. 2018. Sistem Pakar Diagnosa Penyakit Ibu Hamil menggunakan Metode Certainty Factor (CF). Jurnal Pengembangan Teknologi Informasi dan Ilmu Komputer Vol. 2, No. 5, Mei 2018, hlm. 2127-2134.

Hidayat. 2016. Makalah Tutorial Case Servisitis. Fakultas Kedokteran Universitas Pembangunan Nasional Veteran, Jakarta.

Hopcroft, J. E., Rajeev, M., dan Jeffrey, D. U., 2007, Teori Bahasa dan Otomata, Andi.Yogyakarta

Krisnandayu, A. D. dan Pakereng, M. A. I. 2016. Diagnosa Penyakit Hemeroid Menggunakan Finite State Automata.
Artikel Ilmiah Universita Kristen Satya Wacan. Salatiga.

Kurnianto, B. D, Husna, D. Z. dan Mansyur, Z. B. 2016. Sistem Pakar Diagnosa Penyakit Kelamin pada Pria Menggunakan Metode Forward Chaining dan Certainty Factor Berbasis Web. Seminar nasional Teknologi Informasi dan Multimedia STMIK AMIKOM Yogyakarta, 6-7 Februari 2016.

Melly, R.I., Wamiliana dan Kurniawan, D. 2012. Penerapan Konsep Finite State Automata (FSA) pada Mesin Pembuatan Minumam Kopi Otomatis. Jurnal Komputasi, Desember 2012, Vol 1, No. 1.

Mulyanto, S. T. E., dan Suhartono, V. 2010. Kecerdasan Buatan. Andi, Yogyakarta.

Raharja, C. A. 2018. Laporan Data Penderita Penyakit Servisitis. Sukoharjo: Klinik Utama Raharja.

Sarosa, S. 2017. Metodologi Pengambangan Sistem Informasi. Indeks, Jakarta.

Setyaputri, K. E., Fadlil, A., dan Sunardi. 2018. Analisis Metode Certainty Factor pada Sistem Pakar Diagnosa Penyakit THT. Jurnal Teknik Elektro, Vol. 10(1), pp. 30-35.

Sutojo, Edv. 2011. Kecerdasan Buatan.Andi Yogyakarta. Yogyakarta.

Utdirartatmo, F., 2005. Teori Bahasa dan Otomata. Graha Ilmu. Yogyakarta. 